\title{
ОСОБЕННОСТИ АДМИНИСТРАТИВНЫХ ПРАВОНАРУШЕНИЙ В СФЕРЕ МИГРАЦИИ В УКРАИНЕ
}

\author{
НОВИЧЕНКО Андрей - аспиранТ Харьковского национального университета \\ внутренних дел \\ УДК: 342.951:314.15](477) \\ DOI 10.32782/LAW.2020.3.9
}

В статъе рассматриваются вопросъ административной ответственности за нарушения в сбере миграционного права. Проанализирован состав административных правонарушений, за нарушения законодательства в сфере миграции в Украине. Правонарушения разделенъ на две группъ предполагағоие административную ответственность для самих трудовъгх мигрантов и предполагающие административную ответственность для их работодателей и принимающих лии. Исследовано место административнъих правонарушений в сбере миграционного права. Также раскрываться само понятие «административное правонарушение» и субъект административного правонарушения. Рассмотрено видв запретов в иммиграчии по законодательству Украинъ .

Ключевъе слова: миграчия, правонарушение, иммиграчия, разрешение, иностранеи, гражданин, административное право.

Постановка проблемы

Выделение особенностей административных правонарушений в Украине, как одного из способ противодействия нелегальной миграции, способствующих внедрению действенных мер по борьбе с преступностью, связанной с нелегальной миграцией.

\section{Анализ последних исследований}

Изучение этого вопроса занимались такие украинские ученые Ю. Бузицький, А. Бабенко, С. Бритченко, А. Войцеховский, Ко- валенко, В.Кривенко, О.Кузьменко, В.Куц, О. Джужа, Ю. Кравченко, А. Малиновская, А. Надён, А. Черняк, С. Чехович, А. Пискун, И. Прибыткова, Ю. Рымаренко, В. Трощинский, В. Шакуни и др., так и зарубежные ученые Дж. Солт, М. Вийерс, Р. Хавсман, Р. Вольвенд, В. Аунеев, П. Холмс, М. Пугло, А. Шлоенхард и др.

\section{Цель статьи}

Выделить и проанализировать особенности административних правонарушений в сфере нелегальной (незаконной) миграции в Украине.

Изхожений основного материала

Административное правонарушение в миграционном праве - это действие, поведение или бездействие человека, это акт внешнего проявления отношения человека к реальности, другим людям, государству и обществу. Такое деяние следует признать административным правонарушением, если существуют определенные признаки, которые традиционно приписываются общественному ущербу, противоправности, вине и административному наказанию. Общественный вред действий в сфере регулирования миграционных процессов в Украине означает, что действие или бездействие причиняет или угрожает причинить определенный вред (материальный, моральный, организационный или иной) миграционным общественным отношениям. Неправомерное поведение означает, что действие 


\section{Адміністративне право}

или бездействие в законодательстве прямо называется правонарушением.

Действия, признанные административными правонарушениями в области регулирования миграции, перечислены в главе 14 специальной части раздела II Кодекса Украины об административных правонарушениях и в некоторых других нормативных актах. В случае установления административной ответственности за новые действия или отмены ранее существовавшей ответственности необходимо вносить изменения в Кодекс Украины об административных правонарушениях [1] и другие законы Украины.

Место, время, ситуация, метод, инструменты и средства совершения проступка могут быть незаменимыми, если они включены в конкретный состав признаков проступка (например, часть 3 статьи 206-1 Кодекса Украины об административных правонарушениях - перевозка иностранцев и лиц без гражданства в оборудованных владельцами транспортных средствах или специальных скрытых местах для перевозки людей - указывает конкретный способ совершения правонарушения или использования определенных средств). Статья 2041 Кодекса Украины об административных правонарушениях предусматривает административную ответственность за незавершенные действия (попытки пересечь государственную границу Украины любым способом за пределами пунктов пересечения границы Украины), но нет общего правила относительно этапов административного преступления, которое полностью оправдано. Субъективная сторона административного правонарушения связана с совершением психической деятельности человека. Характеристики включают вину, мотив и цель преступления.

Преступление было совершено по небрежности, когда человек предвидел возможность вредных последствий своего действия или бездействия, но ложно рассчитывал на их предотвращение или не предвидел возможности таких последствий, хотя он должен был и мог их предвидеть (потеря паспорта) - статья 198.

Субъект административного правонарушения определяется применимым Ко- дексом об административных правонарушениях как здравомыслящий человек, достигший (к моменту совершения проступка) возраста, с которого начинается административная ответственность. В дополнение к этим общим признакам в конкретных составах субъект также может характеризоваться дополнительными специфическими свойствами. Такие объекты называются специальными объектами. К ним относятся, например, должностные лица (статья 204); лица, ответственные за соблюдение правил паспортной системы (статья 199); владельцы или водители транспортных средств(ст. 206-1); капитаны иностранных судов(ст. 207) и т. д. Все признаки административного проступка взаимосвязаны и взаимозависимы, что делает его полным системным образованием.

Согласно Закону Украины «Об иммиграции» [2], иммиграция - это прибытие в Украину или выезд в Украину иностранцев и лиц без гражданства на постоянное место жительства в законном порядке. Иммигрант - это иностранец или лицо без гражданства, которые получили разрешение на иммиграцию и прибыли в Украину на постоянное жительство, или, находясь в Украине на законных основаниях, получили разрешение на иммиграцию и остались в Украине на постоянное место жительства.

Что касается запрета иммиграции по законодательству Украины: вопросы иммиграции регулируются Конституцией Украины, Законом Украины «Об иммиграции» и другими нормативными правовыми актами, которые не должны им противоречить. Если международным договором Украины, согласие на который предоставлено Верховной Радой Украины, установлены правила, отличные от тех, которые содержатся в упомянутом законе, то применяются правила международного договора Украины.

Государственная миграционная служба Украины имеет основные задачи: реализация государственной политики в сфере миграции (иммиграция и эмиграция), в том числе борьба с нелегальной миграцией, гражданство, регистрация физических лиц, беженцев и других категорий мигрантов, определенных законом; внесение министру 
внутренних дел предложений по обеспечению формирования государственной политики в сфере миграции (иммиграции и эмиграции), в том числе борьбы с нелегальной миграцией, гражданства, регистрации физических лиц, беженцев и других категорий мигрантов, определенных законом. Одна из основных функций: ГМС проводит анализ миграционной ситуации в Украине, проблем беженцев и других категорий мигрантов, разрабатывает текущие и долгосрочные прогнозы по этим вопросам; готовит предложения по определению иммиграционной квоты на календарный год; принимает решение о выдаче разрешения на иммиграцию, об отказе в его выдаче и отзыве такого разрешения. [3, 4]

В соответствии со статьей 4 Закона Украины «Об иммиграции» разрешение на иммиграцию выдается в пределах иммиграционной квоты. Квота иммиграции устанавливается Кабинетом Министров Украины. Иммиграция вне квоты предоставляется:

- одному из супругов, если другой (с которым человек состоит в браке более двух лет) является гражданином Украины, детям и родителям граждан Украины;

- лица, которые являются опекунами или содержателями граждан Украины или находятся под опекой граждан Украины;

- лица, которые имеют право на получение гражданства Украины по территориальному происхождению;

- лица, иммиграция которых представляет национальный интерес для Украины.

Закон запрещает иммиграционные разрешения:

- лицам, приговоренным к лишению свободы на срок более одного года за совершение деяния, которое в соответствии с законодательством Украины признается преступлением, если судимость не погашена или не снята;

- лицам, которые совершили преступление против мира, военное преступление или преступление против человечности, как они определены в международном праве, или разыскиваются в связи с совершением деяния, признанного в соответствии с законодательством Украины серьезным преступлением, или против которых возбуждено уголовное дело, если предварительное следствие не завершено;

- лицам, страдающим хроническим алкоголизмом, токсикоманией, наркоманией или инфекционными заболеваниями, перечень которых определен центральным органом здравоохранения;

- лицам, которые в своих заявлениях на получение разрешения на иммиграцию предоставили заведомо ложную информацию или представили поддельные документы;

- лицам, которым запрещен въезд на территорию Украины по закону;

- в других случаях, предусмотренных законами Украины.

Вина является основной и обязательной чертой субъективной стороны любого административного проступка. Именно психическое отношение человека к социально вредному деянию и его последствиям проявляется в форме умысла или небрежности. Концепция раскрыта в статьях 10 и 11 Кодекса Украины об административных правонарушениях. Административное правонарушение признается преднамеренным, когда лицо, которое совершило его, осознавало незаконный характер его действия или бездействия, предвидело его вредные последствия и хотело их или сознательно допускало возникновение этих последствий (например, преднамеренное повреждение паспорта - статья 198; несоблюдение правил паспортной системы, проживание граждан без паспортов - статья 199; нарушение порядка предоставления иностранцам и лицам без гражданства жилья, транспортных средств и помощи в предоставлении других услуг - статья 199; оборудование собственниками или водителями транспортных средств специально скрытых или скрытых мест, используемых для перевозки нелегальных мигрантов - часть 2 статьи 206-1 Кодекса об административных правонарушениях и т. д.).

Аицу, постоянно проживающему за пределами Украины, которое, наконец, получило разрешение на иммиграцию, дипломатическим представительством или консульским учреждением Украины выдается иммиграционная виза по его / её запросу. 


\section{Адміністративне право}

у статті розглядаються питання адміністративної відповідальності за порушення в сфбері міграиійного права. Проаналізовано склад адміністративних правопорушень, за порушення законодавства у сфері міграиї в Україні. Правопорушення розділені на дві групи передбачають адміністративну відповідальність для самих трудових мігрантів $i$ передбачають адміністративну відповідальність для їх роботодавиів $і$ приймають осіб. Досліджено місце адміністративних правопорушень в сбері міграчійного права. Також розкриватися саме поняття «адміністративне правопорушення» $i$ суб'єкт адміністративного правопорушення. Розглянуто види заборон в імміграчї̈ за законодавством України.

Ключові слова: міграчія, правопорушення, імміграчія, дозвіл, іноземець, громадянин, адміністративне право.

Закон предусматривает следующие основания для отзыва разрешения на иммиграцию:

- в случае, если выясняется, что разрешение было предоставлено на основании заведомо ложных сведений, поддельных документов или утраченных документов;

- иммигрант был приговорен к лишению свободы в Украине на срок более одного года, и приговор суда вступил в законную силу;

- действия иммигранта представляют угрозу национальной безопасности Украины, общественному порядку в Украине;

- это необходимо для защиты здоровья, прав и законных интересов граждан Украины;

- иммигрант нарушил закон о правовом статусе иностранцев и лиц без гражданства;

- в других случаях, предусмотренных законами Украины.

Лицо может повторно подать заявление на получение разрешения на иммиграцию не позднее, чем через год после принятия решения об отказе или отмене разрешения на иммиграцию.

\section{SUMMARY}

The article deals with the issues of administrative responsibility for violations in the field of migration law. The composition of administrative offenses for violations of legislation in the field of migration in Ukraine is analyzed. Offenses are divided into two groups, implying administrative responsibility for the labor migrants themselves and assuming administrative responsibility for their employers and recipients. The place of administrative offenses in the field of migration law has been investigated. Also, the very concept of "administrative offense" and the subject of an administrative offense should be revealed. The types of prohibitions in immigration under the legislation of Ukraine are considered.

Key words: migration, offense, immigration, permission, foreigner, citizen, administrative law.

Что касается статистики, то за 9 месяцев 2019 года Государственная миграционная служба наложила 45415186 штрафов на нарушителей миграционного законодательства. В разрешении на иммиграцию было отказано 202 раза. 1889 разрешений на иммиграцию были отменены [5].

\section{Аитература}

1) Кодекс Украины об административных правонарушениях. Режим электронного доступа: https://zakon.rada.gov.ua/laws/ show/80731-10

2) Закон Украины «Об иммиграции». Режим электронного доступа: https://zakon. rada.gov.ua/laws/show/2491-14

3) Сайт Государственной миграционной службы Украины. Историческая справка. Режим электронного доступа: https://dmsu. gov.ua/pro-dms/zagalna-informacziya.html

4) Постановление Кабинета Министров Украины от 20 августа 2014 года № 360. Положение о Государственной миграционной службе Украины. Режим электронного доступа: http://zakon5.rada.gov.ua/laws/ show/360-2014-\%D0\%BF

5) Статистика Государственной миграционной службы (2019). Официальный сайт ГМС. Режим электронного доступа: https:/ dmsu.gov.ua/assets/files/statistic/year/2019_9.pdf 